\title{
Trafficking regulation of proteins in Alzheimer's disease
}

\author{
Shangtong Jiang ${ }^{1,2+}$, Yanfang $\mathrm{Li}^{2+}$, Xian Zhang ${ }^{2}$, Guojun Bu ${ }^{2,3}$, Huaxi $\mathrm{Xu}^{1,2,4}$ and Yun-wu Zhang ${ }^{2^{*}}$
}

\begin{abstract}
The $\beta$-amyloid (A $B$ ) peptide has been postulated to be a key determinant in the pathogenesis of Alzheimer's disease (AD). A is produced through sequential cleavage of the $\beta$-amyloid precursor protein (APP) by $\beta$ - and $\gamma$-secretases. APP and relevant secretases are transmembrane proteins and traffic through the secretory pathway in a highly regulated fashion. Perturbation of their intracellular trafficking may affect dynamic interactions among these proteins, thus altering $A \beta$ generation and accelerating disease pathogenesis. Herein, we review recent progress elucidating the regulation of intracellular trafficking of these essential protein components in AD.
\end{abstract}

Keywords: $\alpha$-secretase, Amyloid beta (A4) precursor protein, $\beta$-secretase, Beta-site APP-cleaving enzyme 1, Y-secretase, A Disintegrin and Metalloprotease 10, Alzheimer's disease, Trafficking

\section{Introduction}

Alzheimer's disease (AD) is a progressive neurodegenerative disorder characterized clinically by cognitive and memory dysfunction, accompanied by classical hallmark pathologies such as intraneuronal neurofibrillary tangles (NFTs) and extracellular amyloid plaques [1-3]. NFTs are enriched with hyperphosphorylated microtubule-associated protein tau (MAPT) [2], which can be phosphorylated by multiple protein kinases. Amyloid plaques comprise a heterogeneous population of proteolyticallygenerated small $\beta$-amyloid peptides $(A \beta)[1,4,5]$. Mounting evidence indicates that overproduction/aggregation of $A \beta$ in the brain is a primary cause of AD. According to the "amyloid cascade hypothesis", neurotoxic A $\beta$ may trigger a cascade of complex neurodegenerative events leading to synaptic dysfunction, NFT formation and eventually neuron loss in affected brain areas [6-9].

$\mathrm{A} \beta$ is generated from amyloid beta (A4) precursor protein (APP). APP can be processed by amyloidogenic and non-amyloidogenic pathways. Amyloidogenic processing involves initial APP cleavage by $\beta$-secretase within the ectodomain, leading to the release of a soluble APP fragment called SAPP $\beta$. The remaining membrane-anchored

\footnotetext{
* Correspondence: yunzhang@xmu.edu.cn

${ }^{\dagger}$ Equal contributors

${ }^{2}$ Institute of Neuroscience, College of Medicine, Xiamen University, Xiamen, Fujian 361102, China

Full list of author information is available at the end of the article
}

APP $\beta$-carboxyl-terminal fragment $(\beta$-CTF) is then cleaved by the $\gamma$-secretase complex within the lipid bilayer, resulting in the production of $A \beta$ peptide and the APP intracellular domain (AICD). Alternatively, processing within the non-amyloidogenic pathway involves APP cleavage by $\alpha$-secretase within the A $\beta$ domain. The $\alpha$ cleavage releases the extracellular domain of APP called sAPP $\alpha$. The remaining membrane-bound fragment is called APP $\alpha$-CTF and can be further processed by $\gamma$ secretase to generate AICD and a $\mathrm{p} 3$ peptide that is rapidly degraded $[1,10]$. Whether APP is processed through the amyloidogenic pathway by $\beta$-secretase or through the non-amyloidogenic pathway by $\alpha$-secretase greatly depends on colocalization between APP and these secretases, which in turn is dependent on their subcellular codistribution. Hence, comprehensive elucidation of the mechanisms responsible for regulating the intracellular trafficking of APP and related secretases are important aspects in our understanding of $\mathrm{AD}$ and $\mathrm{AD}$ pathogenesis.

\section{Regulated trafficking of APP}

$A P P$ and its trafficking route within the cell

APP is a ubiquitously-expressed type I transmembrane protein belonging to a family comprising three members: APP, APP-like protein 1 and APP-like protein 2, all of which share a highly conserved extracellular region containing Kunitz protease inhibitor (KPI), E1 and E2 domains $[11,12]$. However, only APP contains the A $\beta$ region. 
There are three major APP protein isoforms: APP770, APP751 and APP695. The longer isoforms APP770 and APP751 contain the KPI domain, whereas APP695 is devoid of this domain and is the predominant isoform expressed in the brain $[13,14]$. APP participates in multiple cellular events including cell adhesion, neurite outgrowth, neuronal migration, protein transport, cell signaling and synaptogenesis. For a more complete review on the function of APP please see [1]

Full-length APP is synthesized in the endoplasmic reticulum (ER) and transported through the Golgi/transGolgi network (TGN) apparatus where APP undergoes posttranslational modifications such as glycosylation and phosphorylation during maturation. TGN is also the major site of resident APP in neurons [15-17]. Full-length APP can be transported to the cell surface in TGNderived secretory vesicles. At the plasma membrane APP is either cleaved by $\alpha$-secretase to produce sAPP $\alpha$ [18] or re-internalized within clathrin-coated vesicles to the endosome. APP in the endosome can either be recycled back to cell surface or be delivered to the lysosome for degradation (Figure 1) $[19,20]$. A $\beta$ production involves multiple intracellular organelles [15-17,21,22]. Typically, increased APP delivery to or decreased APP internalization from the cell surface favors the non-amyloidogenic processing, whereas elevated retention of APP in acidic compartments such as endosomes promotes amyloidogenic processing and consequent $A \beta$ production.

\section{APP structure and post-translational modification affect its trafficking}

The intracellular domain of APP is key in regulating APP trafficking through interactions with various cytosolic trafficking factors. A highly conserved YENPTY motif (amino acids 682-687 in APP695) within APP intracellular domain is the major binding site for a number of intracellular adaptors such as APP-binding, family A (APBA, previously called MINT) members and APP-binding, family B, member 1 (APBB1, previously called Fe65) [23]. Mutation within this motif can attenuate the internalization of APP, thereby decreasing A $\beta$ generation [24]. Recently, the extracellular domain of APP has also been shown to affect its trafficking: the KPI domain located in the APP751 extracellular region promotes sorting of APP751 to the plasma membrane, accompanied by decreased $A \beta$ formation in comparison to the neuronal enriched, KPI domain-absent APP695 isoform. Mutation in the KPI domain of APP751 results in its retention in the ER and elevated $\mathrm{A} \beta$ production [25].

APP can be phosphorylated at sites S655 and T668 (based on APP695 numbering) and APP phosphorylation may also affect its trafficking. A YTSI (amino acids 653-656 in APP695) motif within the APP intracellular domain is associated with APP internalization and Golgi polarized sorting in MDCK epithelial cells; and phosphorylation of S655 within this motif promotes APP retrieval from the endosome to TGN [26,27]. Phosphorylation of APP T668

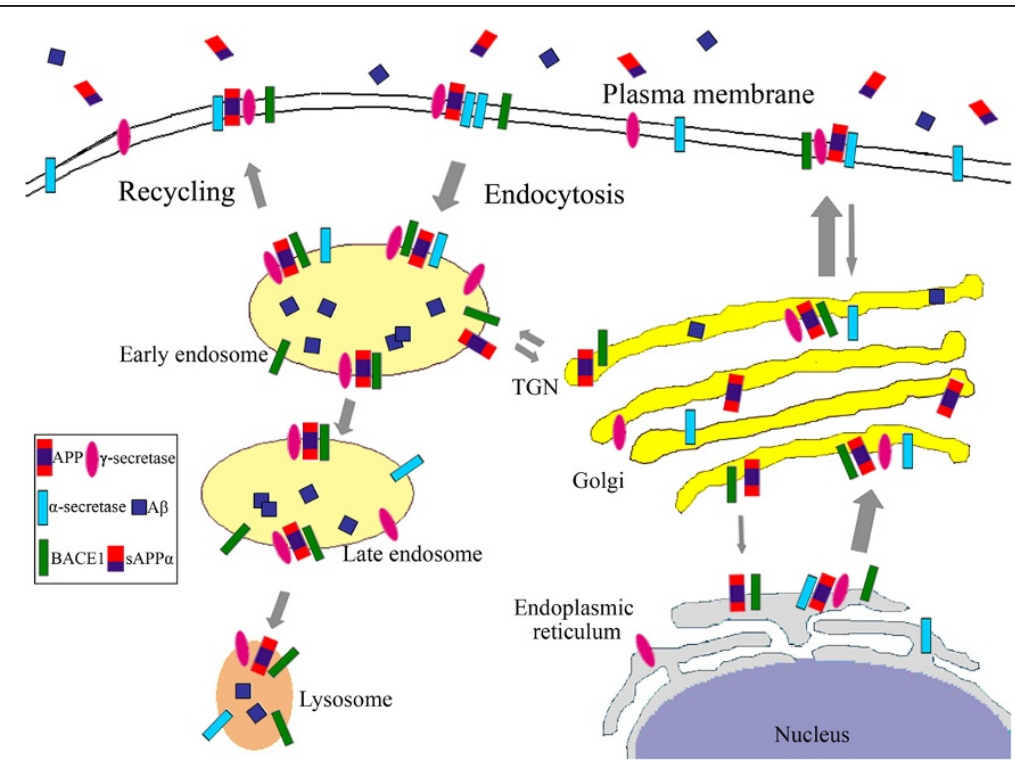

Figure 1 Typical trafficking route of APP, BACE1, a-secretase and $\boldsymbol{\gamma}$-secretase. Newly synthesized APP, BACE1, a-secretase and $\gamma$-secretase traffic through the secretory pathway, from the ER to Golgi/TGN and to the plasma membrane, during which process retrieval may occur and APP may be cleaved to generate A $\beta$. At the plasma membrane APP is largely subjected to non-amyloidogenic processing by a-secretase to release sAPPa. Un-cleaved APP and various secretases at the plasma membrane may undergo endocytosis via early endosome to late endosome/lysosome for degradation. Acidic endosome/lysosome provides optimal environment for BACE1 activity and APP is mainly subjected to amyloidogenic processing for $A \beta$ production in these compartments. In addition, a fraction of these proteins in endosome can be either recycled back to plasma membrane or retrieved back to TGN. 
facilitates amyloidogenic APP processing and A $\beta$ generation [28]. Although direct evidence linking T668 phosphorylation and APP trafficking is scarce, T668 phosphorylation may interfere APP's interaction with other proteins and thus potentially affect its processing/trafficking [29]. Indeed, phosphorylated APP is found to be preferentially enriched at nerve terminals and plasma membrane in neurons, and accumulates in pathological damaged regions of $\mathrm{AD}$ brains [30].

APP can be ubiquitinated for its proteasomal degradation. But ubiquitination of APP may also inhibit its endocytosis to endosomal compartment and thereby lower $A \beta$ generation. In support of this notion, the E3 ubiquitin ligase component FBL2 can promote APP ubiquitination and suppress its endocytosis [31]. In addition, an ubiquitin-like protein, ubiquilin-1 (UBQLN1), can stimulate K63-linked polyubiquitination at APP K688 to inhibit APP maturation and delay APP proteolytic processing through APP sequestration primarily within the Golgi apparatus [32,33]. Interestingly, variants in the UBQLN1 gene have been proposed to be associated with $\mathrm{AD}$ [34], implying that UBQLN1-mediated APP trafficking/ processing might be altered in AD.

\section{The LDLR family in APP trafficking}

The low density lipoprotein receptor (LDLR) family consists of a number of cell surface receptors of diverse functions, including the LDLR, LDLR-related protein 1 (LRP1), LDLR-related protein 1B (LRP1B), LDLR-related protein 2 (LRP2), LDLR-related protein 4 (LRP4), LDLRrelated protein 5 (LRP5), LDLR-related protein 6 (LRP6), LDLR-related protein 8 (LRP8, also known as APOER2), LDLR-related protein 10 (LRP10), LDLR class A domain containing 3 (LDLRAD3), sortilin-related receptor, (LDLR class) A repeats containing (SORL1, also known as SorLA or LR11), etc. [35,36]. Many LDLR family members act as receptors for apolipoprotein $\mathrm{E}$ (APOE), whose allelic polymorphisms are strongly associated with late-onset $\mathrm{AD}$ [37], further implicating the involvement of LDLR family members in AD. Recently several LDLR family members have been shown to modulate APP trafficking/processing. For example, LRP1 can bind APP directly or indirectly through the adaptor protein APBB1/Fe65 and promote rapid APP endocytosis to early endosomes to promote $A \beta$ production $[38,39]$. In contrast LRP1B can compete with LRP1 for APP interactions and due to its comparatively slow rate of endocytosis compared to LRP1, LRP1B retains APP at cell surface and suppresses A $\beta$ generation $[40,41]$.

Another LDLR family member, LRP8/APOER2 can interact with APP intracellularly via APBA/MINT and DAB1 $[42,43]$ or extracellularly via SPON1 (also known as f-spondin) [44]. APP trafficking and resultant nonamyloidogenic or amyloidogenic processing is dependent on the nature of LRP8/APOER2 and APP interactions (intracellularly or extracellularly) and specific linker proteins involved. A new member of LDLR family, LRP10, is found to shuttle between plasma membrane, TGN and endosome $[45,46]$, and interacts with the APP ectodomain to sequester APP in Golgi compartments, thereby reducing APP $\beta$-processing and consequent $\mathrm{A} \beta$ generation [47].

The best characterized LDLR family member in AD is SORL1, a multifunctional neuronal receptor that binds APOE and APP. Genetic studies have identified multiple inherited variants in the SORL1 gene associated with late-onset $\mathrm{AD}$ [48-51]. In addition, SORL1 level is decreased dramatically in frontal cortex and lymphoblasts from AD patients [52]. A correlation between decreased SORL1 expression and impaired cognitive function is also observed [53]. Although the exact physiological function of SORL1 has yet to be determined, its homology with sorting receptors that are involved in the transportation between plasma membrane, endosomes and Golgi suggests the protein trafficking function of SORL1 [54,55]. Indeed, SORL1 has been found to localize mainly in late endosomal and Golgi compartments and overexpression of SORL1 redistributes APP to the Golgi and reduces $A \beta$ generation, whereas downregulation of SORL1 promotes APP sorting into $\mathrm{A} \beta$-generating compartments to aggravate $\mathrm{A} \beta$ production [51,56-58]. These data indicate that SORL1 plays important roles in $\mathrm{AD}$ pathology by regulating the localization and processing of APP.

\section{The RAB GTPase family in APP trafficking}

RABs comprise a subfamily of small molecular weight GTPases within the RAS superfamily which regulates cellular trafficking. In humans, over 60 RAB family members have been described so far [59]. RABs function as molecular switches, alternating between active GTP-bound and inactive GDP-bound forms [60]. RABs regulate protein transport mainly by tethering/docking vesicles to target compartments [60]. Multiple RABs have been implicated in regulating APP trafficking. For example, RAB1B plays a key role in APP transport from the ER to Golgi. A dominant-negative RAB1B mutant blocks APP ER/Golgi transport and significantly inhibits $A \beta$ secretion [61]. In addition, RAB6 functions as a negative regulator of APP anterograde transport through TGN or as a positive modulator of APP retrograde transport from post-Golgi vesicles back to TGN or Golgi cisternae; and a dominant-negative RAB6 mutant facilitates the anterograde transport of APP in the secretory pathway to promote $\alpha$-cleavage [62]. Furthermore, RAB8 facilitates APP transport between the Golgi apparatus and plasma membrane and mutations in $\mathrm{RAB} 8$ results in the reduction of $\mathrm{sAPP} \alpha$ secretion $[63,64]$. 


\section{The SNX family in APP trafficking}

Sorting nexins (SNXs) are a diverse group of cellular trafficking proteins that characteristically comprise a canonical phospholipid-binding domain. The ability of SNXs to bind specific phospholipids, as well as their propensity to form protein-protein complexes, suggests a role for these proteins in membrane trafficking and protein sorting $[65,66]$. Recently, several SNX members have been found to participate in APP metabolism/A $\beta$ generation: SNX33 interacts with the endocytic GTPase dynamin and overexpression of SNX33 reduces the rate of APP endocytosis in a dynamin-dependent manner, leading to enhaced $\alpha$-cleavage at the cell surface [67]. In addition, SNX17 can bind to APP in the early endosome and SNX17 downregulation causes a decline in steady-state levels of APP with a concomitant increase in A $\beta$ production [68].

\section{The APBA/MINT family in APP trafficking}

The APBA/MINT family is an adaptor protein family comprising APBA1/MINT1, APBA2/MINT2 and APBA3/ MINT3. All three proteins are enriched in neurons and contain a phosphotyrosine binding (PTB) domain in the central region and two tandem carboxyl-terminal PDZ (PSD-95, Drosophila disks-large, ZO-1) domains. Mounting evidence indicates that the APBA/MINT family is involved in multiple cellular activities relevant to neuronal protein transport and consequent synaptic function [69-71]. APBA/MINT proteins can interact with the APP YENPTY motif through their PTB domains to fine-tune APP trafficking and processing [70,71]. For instance, APBA1/MINT1 has been found to modulate both secretory and endocytic trafficking of APP and its metabolism [71]. In addition, APBA2/MINT2 can be phosphorylated by SRC to accelerate APP endocytosis and enhance APP sorting to autophagosomes, leading to enhanced intracellular $\mathrm{A} \beta$ accumulation. Conversely, an APBA2/ MINT2 phospho-resistant mutant promotes APP trafficking in the recycling pathway to the cell surface, thus enhancing $A \beta$ secretion [72]. Furthermore, APBA1/MINT1 or APBA2/MINT2 may function as a linker to mediate co-endocytosis of LRP8/APOER2 and APP, thereby elevating $\mathrm{A} \beta$ production $[42,73]$. Finally, APBA3/MINT3 also plays an obligatory role in mediating APP trafficking from the TGN to the plasma membrane and its deficiency reroutes APP trafficking to the endosomal/lysosomal pathway [74].

\section{Other proteins involved in APP trafficking}

In addition to general trafficking modulators, several other proteins have also been proposed to regulate APP trafficking. For example, we and others have shown that presenilin 1 (PS1), the catalytic component of the $\gamma$-secretase complex, can regulate APP intracellular trafficking: PS1 deficiency results in increased APP trafficking to the plasma membrane, whereas familiar AD-linked PS1 mutants dramatically reduce cell surface delivery of APP [75]. PS1 has been proposed to interact with APP and this might be a potential mechanism for its function in regulating APP trafficking. Alternatively, PS1 might regulate APP trafficking through interactions with trafficking factors such as RAB family members and phospholipase D1 (PLD1) [76-80]. PLD1 is a phospholipid-modifying enzyme regulating membrane trafficking events and PLD1 overexpression itself also promotes APP transport from TGN to the plasma membrane $[79,80]$.

\section{Regulated trafficking of the $\beta$-secretase BACE1 $B A C E 1$ and its trafficking pathways within the cell}

It is well accepted that beta-site APP-cleaving enzyme 1 (BACE1) is the dominant $\beta$-secetase enzyme for APP [81-84]. BACE1 is a 501 amino acid long type-I transmembrane aspartyl protease comprising a prodomain with significant homology to other aspartyl protease precursors. Overexpression or downregulation of BACE1 induces or inhibits APP processing and $A \beta$ generation both in vitro and in vivo [81-85]. Several studies find that BACE1 level and activity are elevated significantly in AD brain $[86,87]$. In addition, in an APP overexpression AD mouse model, deletion of BACE1 can abolish $A \beta$ pathology and rescue cholinergic dysfunction and memory deficits [88-90]. These findings suggest that BACE1 may be a good therapeutic target for AD treatment. On the other hand, more recent studies have found that in addition to APP, there are other BACE1 substrates including neuregulin $1[91,92]$, p-selectin glycoprotein ligand-1 [93], ST6GAL1 [94], $\beta$-subunits of voltage-gated sodium channels [95], etc. This raises a possibility that inhibition of BACE1 might affect proper processing of these proteins and cause unwanted side effects. BACE1 null mice do develop several phenotypic abnormalities such as reduced body size, hyperactive behavior, decreased grip strength and elevated pain sensitivity $[91,92,96]$. Recently Eli Lilly's BACE1 inhibitor LY2886721 was also found to cause liver toxicity during its Phase 2 clinical trial. However, it is unclear whether abnormal phenotypes found in BACE1 null mice are generated during developmental stages or during aging; and LY2886721-caused liver toxicity is not believed to be attributed to BACE1 inhibition. Furthermore, BACE1 heterozygous knockout mice have no reported abnormal phenotypes so far and heterozygous knockout of BACE1 still can reduce $A \beta$ deposition in AD mice $[97,98]$. Hence, moderate inhibition of BACE1 activity may still be a good strategy for $\mathrm{AD}$ treatment.

Like other aspartic proteases, immature BACE1 containing the short prodomain is initially synthesized in the ER and subsequently transported to the Golgi apparatus where the prodomain is removed by FURIN or 
other FURIN-like proteases [99-102]. Removal of this prodomain leads to a 2-fold increase of BACE1 activity [103]. BACE1 can also be N-glycosylated and mature BACE1 is exported either to the plasma membrane or to the endosomal compartment. Plasma membrane localized BACE1 can be internalized into the endosome, whereby BACE1 can be recycled to the plasma membrane or transferred to late endosomal/lysosomal compartments (Figure 1). As optimal BACE1 activity is achieved in acidified environments, BACE1 is mainly found in acidic subcellular compartments such as endosome [82,104-107]. Therefore, any modulator that can affect BACE1 shuttling between TGN, the plasma membrane and endosome may play a role in APP processing and A $\beta$ generation.

\section{The GGA family in BACE1 trafficking}

Golgi-localized $\gamma$-adaptin ear-containing ADP ribosylation factor binding proteins (GGAs) are a family of monomeric clathrin adaptor proteins that participate in transport of cargo proteins from TGN to endosome [108]. Mammalian GGAs (GGA1, GGA2, and GGA3) all comprise an aminoterminal VHS (VPS-27, Hrs, and STAM), an intermediary GAT (GGA and Tom1) and a carboxyl-terminal GAE ( $\gamma$-adaptin ear) domain [108]. VHS and GAT domains are highly conserved among GGA1, GGA2 and GGA3 [109]. Recruitment of GGAs from the cytosol to TGN is mediated by the GAT domain [109-111]. Subsequent GGA VHS domain binding to the acidic cluster-dileucine (ACDL) sorting motif within the cytoplasmic tails of selective cargo proteins then sorts the selected cargo into clathrin-coated vesicles that are delivered to the endosome [112].

The BACE1 DISLL (amino acids 496-500) sequence is an ACDL motif located in the BACE1 cytoplasmic domain and can be recognized by the GGA VHS domain $[113,114]$. Previous studies indicate that GGA1 modulates BACE1 retrieval from the endosome to TGN in a phosphorylationdependent manner. Serine phosphorylation within the BACE1 DISLL motif enhances BACE1-GGA interaction [115]. Phosphorylated BACE1 is efficiently transported from endosomes to TGN, whereas non-phosphorylated BACE1 enters a direct recycling route to the plasma membrane [114,116,117]. Overexpression of GGA1 decreases $A \beta$ secretion, while suppression of GGA1 conversely elevates $A \beta$ secretion [116]. In addition, a recent study shows that GGA1 but not GGA2 or GGA3 can modulate SORL1 endocytic traffic and consequent APP traffic to the endocytic recycling compartment [118]. Furthermore, mutation of BACE1 S498 to a non-phosphorylatable residue enhances BACE1 targeting to SORL1-positive compartments [118]. In contrast, GGA3 is proposed to mediate targeting of BACE1 to lysosomes for degradation [119-121]. In AD brains, GGA3 level is significantly decreased and inversely correlated with elevated levels of BACE1. Downregulation of GGA3 also increases BACE1 levels [120,121]. Moreover, BACE1 can be ubiquitinated at K501 and a GGA3 mutant with reduced ubiquitin-binding ability fails to regulate BACE1 levels, implying that GGA3 may also regulate $B A C E 1$ via interactions with ubiquitin sorting machinery [122].

\section{The retromer complex and the SNX family in BACE1 trafficking}

The mammalian retromer complex is composed of VPS35, VPS29, VPS26, SNX1 and SNX2 [123]. Retromer is required for protein endosomal sorting and is closely linked to the endosome-to-Golgi retrieval pathway. Retromer was first identified to sort VPS10 from endosome back to the TGN in yeast [123]. Recent studies have identified some retromer interacting proteins including SORL1 [124] and BACE1 [125]. Suppression of VPS35 expression decreases BACE1 trans-Golgi localization and retains BACE1 in the endosome, the optimal environment for BACE1 activity. Consistently, heterozygous deletion of VPS35 in AD mice results in a significant increase in $A \beta$ level in the mouse hippocampus, accompanied with AD-like phenotypes including cognitive memory deficits, defective long-term potentiation (LTP) and impaired postsynaptic glutamatergic neurotransmission in early adult age [125]. One recent study also found that downregulation of VPS35 in neurons results in increased colocalization of APP with the BACE1 in early endosomes and consequently elevated $A \beta$ levels [126]. Similarly, downregulation of another retromer component VPS26 induces the accumulation of BACE1 in endosome [114]. Coincidently, the levels of VPS35 and VPS26 are found to be downregulated in AD [127].

The existence of two SNX family members, SNX1 and SNX2 within the retromer complex has provided a link for SNXs in regulating BACE1 trafficking. SNX6, a SNX2-like retromer regulator, can interact with BACE1 and negatively regulate its retrograde transport from early endosomes to TGN, retaining BACE1 in endosome [128]. We recently identified SNX12 as another BACE1-interacting protein and demonstrated its role in modulating BACE1 trafficking between the cell surface and early endosome [129].

\section{Other proteins involved in BACE1 trafficking}

There is evidence suggesting that endocytosis of APP and BACE1 are spatially separate: in contrast to clathrindependent APP endocytosis, BACE1 internalization to early endosome is found to be regulated by the small GTPase ADP ribosylation factor 6 (ARF6). Modulation of ARF6 levels or its activity affects endosomal sorting of BACE1 and altered APP processing/A $\beta$ production. Furthermore, APP is cleaved by BACE1 in RAB5-positive early endosome and sorting of BACE1 from ARF6-positive towards RAB5-positive early endosome depends on the BACE1 DISLL motif [130]. 
In addition to its carboxyl-terminus, the transmembrane domain of BACE1 may also affect its trafficking. We recently found that the heavy components of the CUTA protein can interact with the BACE1 transmembrane region. Downregulation of CUTA decelerates BACE1 transport from Golgi/TGN to the plasma membrane and reduces steady-state levels of cell surface BACE1, thus resulting in increased $A \beta$ generation [131]. Furthermore, BACE1 can interact with the reticulon family proteins and this is mediated by BACE1 transmembrane domain [132]. The reticulon family has four members, RTN1, RTN2, RTN3 and RTN4 (also known as Nogo), and is involved in various physiological processes such as membrane trafficking, axonal growth and apoptosis [133]. Overexpression of any reticulon protein has been shown to substantially reduce $\mathrm{A} \beta$ production. In neurons, BACE1 mainly colocalizes with RTN3, whose overexpression can block BACE1 in the ER and thus inhibit BACE1 activity for $A \beta$ generation $[134,135]$. Interestingly, receptors of reticulon have also been found to mediate $A \beta$ production but this is through their interaction with APP. Increased interaction between reticulon receptor and APP can reduce surface expression of APP and favors APP $\beta$-cleavage $[136,137]$.

\section{Regulated trafficking of the $\gamma$-secretase complex The $\gamma$-secretase complex}

BACE1-digested APP CTFs are subsequently cleaved by the $\gamma$-secretase complex to release $A \beta$. In addition, $\gamma$-secretase cleaves a series of functionally important substrates such as NOTCH [138] and tyrosinase [139]. $\gamma$-secretase activity is produced from a high molecular weight complex consisting of at least four transmembrane components: presenilin (PS, with two mammalian homologs as PS1 and PS2), nicastrin, anterior pharynxdefective-1 (APH-1), and presenilin enhancer-2 (PEN2) $[140,141]$. PS1/2 have an undetermined number of transmembrane domains [142] and undergo endoproteolytic cleavage to generate PS amino-terminal fragments (NTFs) and CTFs. PS NTF and CTF form a functional heterodimer, each contributing a highly conserved aspartate residue indispensable for $\gamma$-secretase activity [143]. Nicastrin is a type I transmembrane glycoprotein considered to be the scaffolding protein within the $\gamma$-secretase complex. Nicastrin may also act as the $\gamma$-secretase receptor [144]. The seven-transmembrane APH-1 interacts with nicastrin to form a stable intermediate in an early assembly stage of the $\gamma$ secretase complex [140,141], whereas the two-pass transmembrane component PEN2 regulates PS endoproteolysis $[145,146]$. Each of these four components is necessary for $\gamma$-secretase activity and deficiency in any of these factors dramatically impairs the enzymatic activity.

\section{Assembly of the $\mathrm{y}$-secretase complex and its trafficking route within the cell}

Although aspects of $\gamma$-secretase complex formation and distribution have yet to be fully elucidated, a predicted model for the assembly, maturation, and trafficking of the $\gamma$-secretase complex has been proposed. In this model, the four components of the $\gamma$-secretase complex are synthesized in the ER, where they await incorporation into stable complex. Complex formation initially begins with the association of APH-1 and nicastrin to form an early intermediate subcomplex. Full-length PS is then incorporated into and stabilized within the complex. Subsequent assembly of PEN2 drives the conversion of the full-length PS into active NTF/CTF heterodimers in ER and Golgi compartments [140,147]. During its transit through Golgi/ TGN, nicastrin undergoes complete glycosylation, thus transforming the $\gamma$-secretase complex into its mature form. The $\gamma$-secretase complex in large part shuttles between the ER and Golgi, whereas stabilized mature $\gamma$-secretase complex is transported to the plasma membrane. $\gamma$-secretase at the membrane can then undergo endocytosis to endosomes, and subsequent trafficking to late endosomes/multivesicular bodies or the lysosome (Figure 1) [148-151].

\section{Factors regulating $\gamma$-secretase trafficking and activity}

In addition to its function as the catalytic core of the $\gamma$-secretase complex, PS1 has been shown to modulate trafficking of several transmembrane proteins including APP [75]. Since PS1 interacts with a series of trafficking modulator proteins such as RAB family members and PLD1, PS1 might exert its trafficking regulation through these interactions [152]. Conversely, these trafficking modulators may also reciprocally regulate PS1 trafficking. For example, we find that PLD1 interacts with PS1 and overexpression of PLD1 promotes cell surface accumulation of PS1 in an APP-independent manner [153]. A trafficking regulation role has been proposed for APP [154] and we also find that APP can reciprocally regulate the intracellular trafficking of PS1 and other $\gamma$-secretase components. APP deficiency results in elevated transportation of PS1 $/ \gamma$-secretase from TGN to the cell surface, thereby enhancing NOTCH cleavage [153]. Additionally, APP can function as a kinesin-I membrane receptor and mediates axonal transport of PS1 and BACE1 [155].

The recently identified postsynaptic protein ARC also interacts with PS1 and participates in sorting PS1 to early and recycling endosomes to enhance amyloidogenic APP processing. A $\beta$ production can be blocked by interrupting $\mathrm{ARC}$ association with $\mathrm{PS} 1 / \gamma$-secretase and genetic deletion of ARC decreases $A \beta$ load in a transgenic AD mouse model [156].

The G protein-coupled receptor (GPCR) $\beta 2$-adrenergic receptor is associated with PS1 where agonist-induced 
$\beta 2$-adrenergic receptor endocytosis mediates trafficking of $\mathrm{PS} 1 / \gamma$-secretase to late endosomes and lysosomes to enhance A $\beta$ production [157]. Another GPCR, GPR3 is also found to be a modulator of $A \beta$ production: overexpression of GPR3 increases the formation and cell surface localization of the mature $\gamma$-secretase components, accompanied with stimulated $A \beta$ generation but not NOTCH processing. In contrast, GPR3 deficiency prevents $A \beta$ accumulation both in vitro and in vivo. Moreover, GPR3 is highly expressed in normal human brain regions implicated in AD and its level is elevated in sporadic AD brain [158]. Interestingly, recently it was suggested that both $\beta 2$-adrenergic receptor and GPR3 exert their effects on $A \beta$ generation through interacting with $\beta$ arrestin 2, a member of the arrestin family [159]. Arrestins are GPCR-interacting scaffold proteins and can inhibit G protein coupling to GPCRs, leading to GPCR desensitization and even mediating a $\mathrm{G}$ protein-independent signaling pathway [160]. $\beta$-arrestin 2 is found to interact with $\mathrm{APH}-1$, redistribute the $\gamma$-secretase complex toward detergent-resistent membranes and increase its catalytic activity [159]. The degree of $A \beta$ production stimulation is also correlated with GPCR- $\beta$-arrestin 2 binding and receptor trafficking to endocytic vesicles [161]. Moreover, a subset of GPCRs including GPR3 and PTGER2, are found to be associated with APP when internalized via $\beta$-arrestin 2, thereby increasing APP amyloidogenic processing as well [161]. Coincidently, another arrestin family member, $\beta$-arrestin 1, can interact with APH-1 and facilitate the formation of nicastrin/APH-1 subcomplex and mature $\gamma$-secretase complex. $\beta$-arrestin 1 expression is upregulated in the brains of sporadic $\mathrm{AD}$ patients and transgenic $\mathrm{AD}$ mice, whereas deletion of $\beta$-arrestin 1 in $\mathrm{AD}$ mice results in reduced $A \beta$ generation, diminished $A \beta$ pathology and improved cognition [162].

The retention in ER sorting receptor 1 (RER1), a membrane factor mediating protein retrieval from Golgi to the $E R$, has been found to regulate $\gamma$-secretase trafficking. In one study, RER1 was found to bind to the transmembrane region of nicastrin and retrieve unincorporated nicastrin from the cis-Golgi back to the ER. Since RER1 competes with APH-1 for nicastrin binding, depletion of RER1 resulted in elevated $\gamma$-secretase complex assembly/activity and increased $A \beta$ secretion [163]. In another study, RER1 was found to bind to the first transmembrane domain of PEN2 and retrieve unassembled PEN2 to the ER [164]. Both studies suggest that RER1 may be critical in monitoring quality control during $\gamma$-secretase complex assembly. Recently, RER1 overexpression was also shown to decrease both $\gamma$-secretase localization on the cell surface and $A \beta$ secretion, whereas RER1 downregulation had opposite effects [165]. Furthermore, increased RER1 levels could decrease mature APP and increase immature APP, resulting in less surface accumulation of APP [165].
ATP-binding cassette transporter-2 (ABCA2) is a component responsible for retrograde trafficking of lipoprotein-derived cholesterol from late endosome/lysosome to the ER, and has been genetically linked to AD $[166,167]$. It has been recently shown that ABCA2 depletion can reduce $\gamma$-secretase complex formation due to alterations in protein levels, post-translational modification, and subcellular localization of nicastrin, thus affecting the $\gamma$ processing of APP and A $\beta$ generation [168].

\section{Regulated trafficking of the a-secretase ADAM10} a-secretase, ADAM10 and its trafficking route within the cell $\alpha$-secretase-mediated APP cleavage leads to the release of sAPP $\alpha$, and competitively antagonizes APP amyloidogenic processing and $A \beta$ generation. The $\alpha$-secretase processing pathway is Protein Kinase C-dependent and its activity can be modulated by various molecules such as the purinergic P2Y2 receptor, pituitary adenylate cyclase activating polypeptide, muscarinic receptors and NMDA receptors [169-172]. In addition to APP, several other proteins including prion, NOTCH receptors, ephrins, tumor necrosis factor $\alpha$ and cadherins have also been identified as $\alpha$-secretase substrates [119,173-175].

So far, several ADAM (A Disintegrin and Metalloprotease) family members including ADAM9, ADAM10 and ADAM17 have been implicated as potential APP $\alpha$-secretases. These type-I transmembrane ADAM components are prominently expressed in adult central nervous system. However, the expression of ADMA10 is relatively high compare to those of ADAM9 and ADAM17 in neurons [176-178] and conditional knockout of ADAM10 in mouse neurons nearly abolishes neuronal sAPP $\alpha$ generation [179]. Together, this suggests that ADAM10 is the major functional $\alpha$-secretase in neurons $[180,181]$. In AD patients, the protein level of ADAM10, $\alpha$-secretase activity and consequent sAPP $\alpha$ levels are found to be decreased significantly in platelets and temporal cortex regions $[182,183]$. In contrast, ADAM9 and ADAM17 thus far have only been shown to participate in regulated $\alpha$-secretase cleavage $[181,184]$.

Newly-synthesized ADAM10 in the ER has a proprotein convertase recognition sequence between the prodomain and the catalytic regions. During its secretory trafficking to TGN and cell surface (Figure 1), ADAM10 can be cleaved by PC7 or FURIN to yield a mature, active form [185-187]. In neurons, $\alpha$-secretase functions predominantly at the cell surface [188], with minor $\alpha$-secretase activity observed in TGN [189-191].

\section{Regulated trafficking of ADAM10}

An arginine-rich ( $\left.{ }^{723} \mathrm{RRR}\right)$ sequence within the ADAM10 intracellular C-terminal tail is required for its retention in the ER and attenuates trafficking to the cell surface. Mutation of the second arginine within the ${ }^{723} R R R$ 
sequence is sufficient to allow ADAM10 exit from the ER and enhance ADAM10 distribution to the neuronal cell surface [192].

Protein interactions can influence ADAM10 localization. For instance, interactions with synapse-associated protein97 (SAP97), a protein involved in dynamic transport of proteins to the excitatory synapses, facilitates ADAM10 targeting to the postsynaptic membrane. ADAM10-SAP97 interaction is triggered by NMDA receptor activation, thus promoting the non-amyloidogenic processing of APP. Conversely, disrupting ADAM10-SAP97 interaction redistributes ADAM10 localization from postsynaptic membranes, thereby suppresses non-amyloidogenic APP processing. As a consequence, this results in $A \beta$ accumulation, MAPT hyperphosphorylation, and impaired behavioral performance and synaptic dysfunction in mice, thereby recapitulating early-stage AD phenotypes [193]. In the hippocampus of $\mathrm{AD}$ patients, the association of ADAM10 with SAP97 is found to be reduced [194], implying a dysfunction in SAP97-mediated ADAM10 sorting in $\mathrm{AD}$. Interestingly, while long-term depression can promote SAP97-dependent ADAM10 distribution and activity in synaptic membranes, LTP can induce ADAM10 endocytosis and reduce ADAM10 activity through the association of the clathrin-adaptor AP2. Furthermore, ADAM10-AP2 association is found to be enhanced in AD patients [195]. These findings indicate that SAP97 and AP2 are critical components in controlling ADAM10 localization and activity at synapses to modulate pathophysiology in AD.

\section{Conclusions}

Although APP is a well-characterized substrate of $\alpha-, \beta$ and $\gamma$-secretases, the physiological relevance of the various APP processing pathways is far from clear. Amyloidogenic $A \beta$ generation from APP clearly contributes to ADassociated neurotoxicity and plays a central role in the pathogenesis of $\mathrm{AD}$. A wealth of experimental evidence demonstrates APP cleavage by different secretases at distinct cellular sites, implying the importance of the subcellular co-distribution of APP and various secretases in A $\beta$ generation. Indeed, APP processing is a complicated and dynamic process during which a number of adaptors/ linkers, motor molecules and membrane proteins work together to facilitate proper sorting of APP and its secretases. This review covers some of the salient aspects of intracellular trafficking regulation of APP and secretases. Future investigation is expected to enhance our understanding of how dysregulation of protein trafficking can contribute to $\mathrm{AD}$ pathogenesis and may potentially reveal new strategies in $\mathrm{AD}$ treatment.

\section{Abbreviations}

$A \beta$ : $\beta$-amyloid; ABCA2: ATP-binding cassette transporter-2; ACDL: Acidic cluster-dileucine; AD: Alzheimer's disease; ADAM: A Disintegrin and
Metalloprotease; AICD: APP intracellular domain; APBA: APP-binding, family A; APBB1: APP-binding, family B member 1; APOE: Apolipoprotein E;

APP: Amyloid beta (A4) precursor protein; ARF6: ADP ribosylation factor 6 ; BACE1: Beta-site APP-cleaving enzyme 1; CTF: Carboxyl-terminal fragment;

DS: Down syndrome; ER: Endoplasmic reticulum; GAE: $\gamma$-adaptin ear; GAT: GGA and Tom1; GGA: Golgi-localized $y$-adaptin ear-containing ADP ribosylation factor binding protein; GPCR: G protein-coupled receptor; KPI: Kunitz protease inhibitor; LDLR: Low density lipoprotein receptor; LDLRAD3: LDLR class A domain containing 3; LRP1: LDLR-related protein 1; LRP1B: LDLR-related protein 1B; LRP2: LDLR-related protein 2; LRP4: LDLR-related protein 4; LRP5: LDLR-related protein 5; LRP6: LDLR-related protein 6; LRP8: LDLR-related protein 8; LRP10: LDLR-related protein 10; LTP: Long-term potentiation; NFTs: Neurofibrillary tangles; NTF: Amino-terminal fragment; PDZ: PSD-95, Drosophila disks-large, ZO-1; PLD1: Phospholipase D1; PS1: Presenilin 1; PTB: Phosphotyrosine binding; RER1: Retention in ER sorting receptor 1; SAP97: Synapse-associated protein-97; SNX: Sorting nexin; SORL1: Sortilin-related receptor, (LDLR class) A repeats containing; TGN: TransGolgi network; VHS VPS-27: Hrs and STAM; UBQLIN1: Ubiquilin-1.

\section{Competing interests}

The authors declare that they have no competing interests.

\section{Authors' contributions}

$\mathrm{SJ}, \mathrm{YL}, \mathrm{XZ}, \mathrm{GB}, \mathrm{HX}$ and $\mathrm{YWZ}$ contributed to the writing and revising of the manuscript. All authors read and approved the final manuscript.

\section{Acknowledgements}

We thank Drs. Timothy Huang and Xin Wang for proofreading this manuscript. This work was supported by grants from the National Institutes of Health (R01AG038710, R01AG021173, R01AG044420 and R01NS046673), the Alzheimer's Association, National Natural Science Foundation of China (81225008, 81000540, 81161120496, 91332112 and 91332114), the Fundamental Research Funds for the Central Universities of China, and Fok Ying Tung Education Foundation.

\section{Author details}

${ }^{1}$ Fujian Provincial Key Laboratory of Neurodegenerative Disease and Aging Research, School of Pharmaceutical Sciences, Xiamen University, Xiamen,

Fujian 361102, China. ${ }^{2}$ Institute of Neuroscience, College of Medicine, Xiamen University, Xiamen, Fujian 361102, China. ${ }^{3}$ Department of Neuroscience, Mayo Clinic, Jacksonville, Florida 32224, USA. ${ }^{4}$ Degenerative Disease Research Program, Sanford-Burnham Medical Research Institute, La Jolla, California 92037, USA.

Received: 29 November 2013 Accepted: 15 December 2013

Published: 11 January 2014

\section{References}

1. Zheng $\mathrm{H}$, Koo EH: Biology and pathophysiology of the amyloid precursor protein. Mol Neurodegener 2011, 6:27.

2. Lee VM, Goedert M, Trojanowski JQ: Neurodegenerative tauopathies. Annu Rev Neurosci 2001, 24:1121-1159.

3. Hippius H, Neundorfer G: The discovery of Alzheimer's disease. Dialogues Clin Neurosci 2003, 5:101-108.

4. Glenner GG, Wong CW: Alzheimer's disease: initial report of the purification and characterization of a novel cerebrovascular amyloid protein. Biochem Biophys Res Commun 1984, 120:885-890.

5. Masters CL, Simms G, Weinman NA, Multhaup G, McDonald BL, Beyreuther K: Amyloid plaque core protein in Alzheimer disease and Down syndrome. Proc Natl Acad Sci USA 1985, 82:4245-4249.

6. Hardy J, Selkoe DJ: The amyloid hypothesis of Alzheimer's disease: progress and problems on the road to therapeutics. Science 2002, 297:353-356.

7. Koffie RM, Hyman BT, Spires-Jones TL: Alzheimer's disease: synapses gone cold. Mol Neurodegener 2011, 6:63.

8. Hardy JA, Higgins GA: Alzheimer's disease: the amyloid cascade hypothesis. Science 1992, 256:184-185.

9. Hoozemans JJ, Chafekar SM, Baas F, Eikelenboom P. Scheper W: Always around, never the same: pathways of amyloid beta induced neurodegeneration throughout the pathogenic cascade of Alzheimer's disease. Curr Med Chem 2006, 13:2599-2605. 
10. Zhang YW, Thompson R, Zhang H, Xu H: APP processing in Alzheimer's disease. Mol Brain 2011, 4:3.

11. Wasco W, Bupp K, Magendantz M, Gusella JF, Tanzi RE, Solomon F: Identification of a mouse brain cDNA that encodes a protein related to the Alzheimer disease-associated amyloid beta protein precursor. Proc Natl Acad Sci USA 1992, 89:10758-10762.

12. Wasco W, Gurubhagavatula S, Paradis MD, Romano DM, Sisodia SS, Hyman BT, Neve RL, Tanzi RE: Isolation and characterization of APLP2 encoding a homologue of the Alzheimer's associated amyloid beta protein precursor. Nat Genet 1993, 5:95-100.

13. de Silva HA R, Jen A, Wickenden C, Jen LS, Wilkinson SL, Patel AJ: Cell-specific expression of beta-amyloid precursor protein isoform mRNAs and proteins in neurons and astrocytes. Brain Res Mol Brain Res 1997, 47:147-156.

14. Kang J, Muller-Hill B: Differential splicing of Alzheimer's disease amyloid A4 precursor RNA in rat tissues: PreA4(695) mRNA is predominantly produced in rat and human brain. Biochem Biophys Res Commun 1990, 166:1192-1200.

15. Xu H, Sweeney D, Wang R, Thinakaran G, Lo AC, Sisodia SS, Greengard P, Gandy S: Generation of Alzheimer beta-amyloid protein in the trans-Golgi network in the apparent absence of vesicle formation. Proc Natl Acad Sci USA 1997, 94:3748-3752.

16. Hartmann T, Bieger SC, Bruhl B, Tienari PJ, Ida N, Allsop D, Roberts GW, Masters CL, Dotti CG, Unsicker K, Beyreuther K: Distinct sites of intracellular production for Alzheimer's disease A beta40/42 amyloid peptides. Nat Med 1997, 3:1016-1020.

17. Greenfield JP, Tsai J, Gouras GK, Hai B, Thinakaran G, Checler F, Sisodia SS, Greengard P, Xu H: Endoplasmic reticulum and trans-Golgi network generate distinct populations of Alzheimer beta-amyloid peptides. Proc Natl Acad Sci USA 1999, 96:742-747.

18. Sisodia SS: Beta-amyloid precursor protein cleavage by a membranebound protease. Proc Natl Acad Sci USA 1992, 89:6075-6079.

19. Nordstedt C, Caporaso GL, Thyberg J, Gandy SE, Greengard P: Identification of the Alzheimer beta/A4 amyloid precursor protein in clathrin-coated vesicles purified from PC12 cells. J Biol Chem 1993, 268:608-612.

20. Caporaso GL, Takei K, Gandy SE, Matteoli M, Mundigl O, Greengard P, De Camilli P: Morphologic and biochemical analysis of the intracellular trafficking of the Alzheimer beta/A4 amyloid precursor protein. J Neurosci 1994, 14:3122-3138.

21. Haass C, Hung AY, Schlossmacher MG, Teplow DB, Selkoe DJ: Beta-Amyloid peptide and a 3-kDa fragment are derived by distinct cellular mechanisms. J Biol Chem 1993, 268:3021-3024.

22. Haass C, Hung AY, Schlossmacher MG, Oltersdorf T, Teplow DB, Selkoe DJ: Normal cellular processing of the beta-amyloid precursor protein results in the secretion of the amyloid beta peptide and related molecules. Ann N Y Acad Sci 1993, 695:109-116.

23. King GD, Scott Turner R: Adaptor protein interactions: modulators of amyloid precursor protein metabolism and Alzheimer's disease risk? Exp Neurol 2004, 185:208-219.

24. Perez RG, Soriano S, Hayes JD, Ostaszewski B, Xia W, Selkoe DJ, Chen X, Stokin GB, Koo EH: Mutagenesis identifies new signals for beta-amyloid precursor protein endocytosis, turnover, and the generation of secreted fragments, including Abeta42. J Biol Chem 1999, 274:18851-18856.

25. Ben Khalifa N, Tyteca D, Marinangeli C, Depuydt M, Collet JF, Courtoy PJ, Renauld JC, Constantinescu S, Octave JN, Kienlen-Campard P: Structural features of the KPI domain control APP dimerization, trafficking, and processing. FASEB J 2012, 26:855-867

26. Vieira SI, Rebelo S, Domingues SC, da Cruz e Silva EF, da Cruz e Silva OA: S655 phosphorylation enhances APP secretory traffic. Mol Cell Biochem 2009, 328:145-154.

27. Vieira SI, Rebelo S, Esselmann H, Wiltfang J, Lah J, Lane R, Small SA, Gandy S, da Cruz ESEF, da Cruz ESOA: Retrieval of the Alzheimer's amyloid precursor protein from the endosome to the TGN is $\mathbf{S 6 5 5}$ phosphorylation state-dependent and retromer-mediated. Mol Neurodegener 2010, 5:40.

28. Lee MS, Kao SC, Lemere CA, Xia W, Tseng HC, Zhou Y, Neve R, Ahlijanian MK, Tsai LH: APP processing is regulated by cytoplasmic phosphorylation. J Cell Biol 2003, 163:83-95.

29. Suzuki T, Nakaya T: Regulation of amyloid beta-protein precursor by phosphorylation and protein interactions. J Biol Chem 2008, 283:29633-29637.
30. Santos SF, Tasiaux B, Sindic C, Octave JN: Inhibition of neuronal calcium oscillations by cell surface APP phosphorylated on T668. Neurobiol Aging 2011, 32:2308-2313.

31. Watanabe T, Hikichi Y, Willuweit A, Shintani $Y$, Horiguchi T: FBL2 regulates amyloid precursor protein (APP) metabolism by promoting ubiquitination-dependent APP degradation and inhibition of APP endocytosis. J Neurosci 2012, 32:3352-3365.

32. El Ayadi A, Stieren ES, Barral JM, Boehning D: Ubiquilin-1 regulates amyloid precursor protein maturation and degradation by stimulating K63-linked polyubiquitination of lysine 688. Proc Natl Acad Sci USA 2012, 109:13416-13421.

33. Hiltunen M, Lu A, Thomas AV, Romano DM, Kim M, Jones PB, Xie Z, Kounnas MZ, Wagner SL, Berezovska O, et al: Ubiquilin 1 modulates amyloid precursor protein trafficking and Abeta secretion. $J$ Biol Chem 2006, 281:32240-32253.

34. Bertram L, Hiltunen M, Parkinson M, Ingelsson M, Lange C, Ramasamy K, Mullin K, Menon R, Sampson AJ, Hsiao MY, et al: Family-based association between Alzheimer's disease and variants in UBQLN1. N Engl J Med 2005, 352:884-894.

35. Herz J, Bock HH: Lipoprotein receptors in the nervous system. Annu Rev Biochem 2002, 71:405-434.

36. Herz J, Gotthardt M, Willnow TE: Cellular signalling by lipoprotein receptors. Curr Opin Lipidol 2000, 11:161-166.

37. Liu CC, Kanekiyo T, Xu H, Bu G: Apolipoprotein E and Alzheimer disease: risk, mechanisms and therapy. Nat Rev Neurol 2013, 9:106-118.

38. Li Y, Marzolo MP, van Kerkhof P, Strous GJ, Bu G: The YXXL motif, but not the two NPXY motifs, serves as the dominant endocytosis signal for low density lipoprotein receptor-related protein. J Biol Chem 2000, 275:17187-17194.

39. Trommsdorff M, Borg JP, Margolis B, Herz J: Interaction of cytosolic adaptor proteins with neuronal apolipoprotein $E$ receptors and the amyloid precursor protein. J Biol Chem 1998, 273:33556-33560.

40. Liu CX, Li Y, Obermoeller-McCormick LM, Schwartz AL, Bu G: The putative tumor suppressor LRP1B, a novel member of the low density lipoprotein (LDL) receptor family, exhibits both overlapping and distinct properties with the LDL receptor-related protein. J Biol Chem 2001, 276:28889-28896.

41. Cam JA, Zerbinatti CV, Knisely JM, Hecimovic S, Li Y, Bu G: The low density lipoprotein receptor-related protein $1 \mathrm{~B}$ retains beta-amyloid precursor protein at the cell surface and reduces amyloid-beta peptide production. J Biol Chem 2004, 279:29639-29646.

42. He X, Cooley K, Chung CH, Dashti N, Tang J: Apolipoprotein receptor 2 and X11 alpha/beta mediate apolipoprotein E-induced endocytosis of amyloid-beta precursor protein and beta-secretase, leading to amyloid-beta production. J Neurosci 2007, 27:4052-4060.

43. Hoe HS, Tran TS, Matsuoka Y, Howell BW, Rebeck GW: DAB1 and Reelin effects on amyloid precursor protein and ApoE receptor 2 trafficking and processing. J Biol Chem 2006, 281:35176-35185.

44. Hoe HS, Wessner D, Beffert U, Becker AG, Matsuoka Y, Rebeck GW: F-spondin interaction with the apolipoprotein E receptor ApoEr2 affects processing of amyloid precursor protein. Mol Cell Biol 2005, 25:9259-9268.

45. Boucher R, Larkin H, Brodeur J, Gagnon H, Theriault C, Lavoie C: Intracellular trafficking of LRP9 is dependent on two acidic cluster/dileucine motifs. Histochem Cell Biol 2008, 130:315-327.

46. Doray B, Knisely JM, Wartman L, Bu G, Kornfeld S: Identification of acidic dileucine signals in LRP9 that interact with both GGAs and AP-1/AP-2. Traffic 2008, 9:1551-1562.

47. Brodeur J, Theriault C, Lessard-Beaudoin M, Marcil A, Dahan S, Lavoie C: LDLR-related protein 10 (LRP10) regulates amyloid precursor protein (APP) trafficking and processing: evidence for a role in Alzheimer's disease. Mol Neurodegener 2012, 7:31

48. Lee JH, Cheng R, Honig LS, Vonsattel JP, Clark L, Mayeux R: Association between genetic variants in SORL1 and autopsy-confirmed Alzheimer disease. Neurology 2008, 70:887-889.

49. Cellini E, Tedde A, Bagnoli S, Pradella S, Piacentini S, Sorbi S, Nacmias B: Implication of sex and SORL1 variants in italian patients with Alzheimer disease. Arch Neurol 2009, 66:1260-1266.

50. Reitz C, Cheng R, Rogaeva E, Lee JH, Tokuhiro S, Zou F, Bettens K, Sleegers K, Tan EK, Kimura R, et al: Meta-analysis of the association between variants in SORL1 and Alzheimer disease. Arch Neurol 2011, 68:99-106.

51. Rogaeva E, Meng Y, Lee JH, Gu Y, Kawarai T, Zou F, Katayama T, Baldwin CT, Cheng $\mathrm{R}$, Hasegawa $\mathrm{H}$, et al: The neuronal sortilin-related receptor SORL1 
is genetically associated with Alzheimer disease. Nat Genet 2007, 39:168-177.

52. Scherzer CR, Offe K, Gearing M, Rees HD, Fang G, Heilman CJ, Schaller C, Bujo H, Levey Al, Lah JJ: Loss of apolipoprotein E receptor LR11 in Alzheimer disease. Arch Neurol 2004, 61:1200-1205.

53. Sager KL, Wuu J, Leurgans SE, Rees HD, Gearing M, Mufson EJ, Levey Al, Lah JJ: Neuronal LR11/sorLA expression is reduced in mild cognitive impairment. Ann Neurol 2007, 62:640-647.

54. Yamazaki H, Bujo H, Kusunoki J, Seimiya K, Kanaki T, Morisaki N, Schneider WJ, Saito $Y$ : Elements of neural adhesion molecules and a yeast vacuolar protein sorting receptor are present in a novel mammalian low density lipoprotein receptor family member. J Bio/ Chem 1996, 271:24761-24768.

55. Jacobsen L, Madsen P, Moestrup SK, Lund AH, Tommerup N, Nykjaer A, Sottrup-Jensen L, Gliemann J, Petersen CM: Molecular characterization of a novel human hybrid-type receptor that binds the alpha2-macroglobulin receptor-associated protein. J Biol Chem 1996, 271:31379-31383.

56. Offe K, Dodson SE, Shoemaker JT, Fritz JJ, Gearing M, Levey Al, Lah JJ: The lipoprotein receptor LR11 regulates amyloid beta production and amyloid precursor protein traffic in endosomal compartments. J Neurosci 2006, 26:1596-1603.

57. Andersen OM, Reiche J, Schmidt V, Gotthardt M, Spoelgen R, Behlke J, von Arnim CA, Breiderhoff T, Jansen P, Wu X, et al: Neuronal sorting protein-related receptor sorLA/LR11 regulates processing of the amyloid precursor protein. Proc Natl Acad Sci USA 2005, 102:13461-13466.

58. Rohe M, Carlo AS, Breyhan H, Sporbert A, Militz D, Schmidt V, Wozny C, Harmeier A, Erdmann B, Bales KR, et al: Sortilin-related receptor with A-type repeats (SORLA) affects the amyloid precursor protein-dependent stimulation of ERK signaling and adult neurogenesis. J Biol Chem 2008, 283:14826-14834.

59. Diekmann Y, Seixas E, Gouw M, Tavares-Cadete F, Seabra MC, Pereira-Leal JB: Thousands of rab GTPases for the cell biologist. PLoS Comput Biol 2011, 7:e1002217.

60. Zerial M, McBride $\mathrm{H}$ : Rab proteins as membrane organizers. Nat Rev Mol Cell Biol 2001, 2:107-117.

61. Dugan JM, de Wit C, McConlogue L, Maltese WA: The Ras-related GTP-binding protein, Rab1B, regulates early steps in exocytic transport and processing of beta-amyloid precursor protein. J Biol Chem 1995, 270:10982-10989.

62. McConlogue L, Castellano F, de Wit C, Schenk D, Maltese WA: Differential effects of a Rab6 mutant on secretory versus amyloidogenic processing of Alzheimer's beta-amyloid precursor protein. J Biol Chem 1996, 271:1343-1348.

63. Huber LA, Pimplikar S, Parton RG, Virta H, Zerial M, Simons K: Rab8, a small GTPase involved in vesicular traffic between the TGN and the basolateral plasma membrane. J Cell Biol 1993, 123:35-45.

64. Huber LA, de Hoop MJ, Dupree P, Zerial M, Simons K, Dotti C: Protein transport to the dendritic plasma membrane of cultured neurons is regulated by rab8p. J Cell Biol 1993, 123:47-55.

65. Cheever ML, Sato TK, de Beer T, Kutateladze TG, Emr SD, Overduin M: Phox domain interaction with Ptdlns(3)P targets the Vam7 t-SNARE to vacuole membranes. Nat Cell Biol 2001, 3:613-618.

66. Ellson CD, Gobert-Gosse S, Anderson KE, Davidson K, Erdjument-Bromage $H$, Tempst P, Thuring JW, Cooper MA, Lim ZY, Holmes AB, et al: Ptdlns(3)P regulates the neutrophil oxidase complex by binding to the $\mathrm{PX}$ domain of p40(phox). Nat Cell Biol 2001, 3:679-682.

67. Schobel S, Neumann S, Hertweck M, Dislich B, Kuhn PH, Kremmer E, Seed B, Baumeister R, Haass C, Lichtenthaler SF: A novel sorting nexin modulates endocytic trafficking and alpha-secretase cleavage of the amyloid precursor protein. J Biol Chem 2008, 283:14257-14268.

68. Lee J, Retamal C, Cuitino L, Caruano-Yzermans A, Shin JE, van Kerkhof $P$, Marzolo MP, Bu G: Adaptor protein sorting nexin 17 regulates amyloid precursor protein trafficking and processing in the early endosomes. J Biol Chem 2008, 283:11501-11508.

69. Rogelj B, Mitchell JC, Miller CC, MCLoughlin DM: The X11/Mint family of adaptor proteins. Brain Res Rev 2006, 52:305-315.

70. Biederer T, Cao X, Sudhof TC, Liu X: Regulation of APP-dependent transcription complexes by Mint/X11s: differential functions of Mint isoforms. J Neurosci 2002, 22:7340-7351.

71. King GD, Perez RG, Steinhilb ML, Gaut JR, Turner RS: X11alpha modulates secretory and endocytic trafficking and metabolism of amyloid precursor protein: mutational analysis of the YENPTY sequence. Neuroscience 2003, 120:143-154.
72. Chaufty J, Sullivan SE, Ho A: Intracellular amyloid precursor protein sorting and amyloid-beta secretion are regulated by Src-mediated phosphorylation of Mint2. J Neurosci 2012, 32:9613-9625.

73. Miller CC, McLoughlin DM, Lau KF, Tennant ME, Rogelj B: The X11 proteins, Abeta production and Alzheimer's disease. Trends Neurosci 2006, 29:280-285.

74. Shrivastava-Ranjan P, Faundez V, Fang G, Rees H, Lah JJ, Levey Al, Kahn RA: Mint3/X11gamma is an ADP-ribosylation factor-dependent adaptor that regulates the traffic of the Alzheimer's Precursor protein from the trans-Golgi network. Mol Biol Cell 2008, 19:51-64.

75. Cai D, Leem JY, Greenfield JP, Wang P, Kim BS, Wang R, Lopes KO, Kim SH, Zheng $\mathrm{H}$, Greengard $\mathrm{P}$, et al: Presenilin-1 regulates intracellular trafficking and cell surface delivery of beta-amyloid precursor protein. J Biol Chem 2003, 278:3446-3454.

76. Dumanchin C, Czech C, Campion D, Cuif MH, Poyot T, Martin C, Charbonnier F, Goud B, Pradier L, Frebourg T: Presenilins interact with Rab11, a small GTPase involved in the regulation of vesicular transport. Hum Mol Genet 1999, 8:1263-1269.

77. Scheper W, Zwart R, Sluijs P, Annaert W, Gool WA, Baas F: Alzheimer's presenilin 1 is a putative membrane receptor for rab GDP dissociation inhibitor. Hum Mol Genet 2000, 9:303-310.

78. Scheper W, Zwart R, Baas F: Rab6 membrane association is dependent of Presenilin 1 and cellular phosphorylation events. Brain Res Mol Brain Res 2004, 122:17-23.

79. Cai D, Netzer WJ, Zhong M, Lin Y, Du G, Frohman M, Foster DA, Sisodia SS, $\mathrm{Xu} \mathrm{H}$, Gorelick FS, Greengard P: Presenilin-1 uses phospholipase D1 as a negative regulator of beta-amyloid formation. Proc Natl Acad Sci USA 2006, 103:1941-1946.

80. Cai D, Zhong M, Wang R, Netzer WJ, Shields D, Zheng H, Sisodia SS, Foster DA, Gorelick FS, Xu H, Greengard P: Phospholipase D1 corrects impaired betaAPP trafficking and neurite outgrowth in familial Alzheimer's diseaselinked presenilin-1 mutant neurons. Proc Natl Acad Sci USA 2006, 103:1936-1940.

81. Sinha S, Anderson JP, Barbour R, Basi GS, Caccavello R, Davis D, Doan M, Dovey HF, Frigon N, Hong J, et al: Purification and cloning of amyloid precursor protein beta-secretase from human brain. Nature 1999, 402:537-540.

82. Vassar R, Bennett BD, Babu-Khan S, Kahn S, Mendiaz EA, Denis P, Teplow DB, Ross S, Amarante P, Loeloff R, et al: Beta-secretase cleavage of Alzheimer's amyloid precursor protein by the transmembrane aspartic protease BACE. Science 1999, 286:735-741.

83. Yan R, Bienkowski MJ, Shuck ME, Miao H, Tory MC, Pauley AM, Brashier JR, Stratman NC, Mathews WR, Buhl AE, et al: Membrane-anchored aspartyl protease with Alzheimer's disease beta-secretase activity. Nature 1999, 402:533-537.

84. Lau KF, McLoughlin DM, Standen C, Miller CC: X11 alpha and $\mathrm{x} 11$ beta interact with presenilin-1 via their PDZ domains. Mol Cell Neurosci 2000, 16:557-565

85. Cai H, Wang Y, McCarthy D, Wen H, Borchelt DR, Price DL, Wong PC: BACE1 is the major beta-secretase for generation of Abeta peptides by neurons. Nat Neurosci 2001, 4:233-234.

86. Yang LB, Lindholm K, Yan R, Citron M, Xia W, Yang XL, Beach T, Sue L, Wong $P$, Price $D$, et al: Elevated beta-secretase expression and enzymatic activity detected in sporadic Alzheimer disease. Nat Med 2003, 9:3-4.

87. Johnston JA, Liu WW, Todd SA, Coulson DT, Murphy S, Irvine GB, Passmore AP: Expression and activity of beta-site amyloid precursor protein cleaving enzyme in Alzheimer's disease. Biochem Soc Trans 2005, 33:1096-1100.

88. Luo Y, Bolon B, Kahn S, Bennett BD, Babu-Khan S, Denis P, Fan W, Kha H, Zhang J, Gong Y, et al: Mice deficient in BACE1, the Alzheimer's betasecretase, have normal phenotype and abolished beta-amyloid generation. Nat Neurosci 2001, 4:231-232.

89. Ohno M, Cole SL, Yasvoina M, Zhao J, Citron M, Berry R, Disterhoft JF, Vassar R: BACE1 gene deletion prevents neuron loss and memory deficits in 5XFAD APP/PS1 transgenic mice. Neurobiol Dis 2007, 26:134-145.

90. Ohno M, Sametsky EA, Younkin LH, Oakley H, Younkin SG, Citron M, Vassar R, Disterhoft JF: BACE1 deficiency rescues memory deficits and cholinergic dysfunction in a mouse model of Alzheimer's disease. Neuron 2004, 41:27-33.

91. Hu X, Hicks CW, He W, Wong P, Macklin WB, Trapp BD, Yan R: Bace1 modulates myelination in the central and peripheral nervous system. Nat Neurosci 2006, 9:1520-1525 
92. Willem M, Garratt AN, Novak B, Citron M, Kaufmann S, Rittger A, DeStrooper B, Saftig P, Birchmeier C, Haass C: Control of peripheral nerve myelination by the beta-secretase BACE1. Science 2006, 314:664-666.

93. Lichtenthaler SF, Dominguez DI, Westmeyer GG, Reiss K, Haass C, Saftig P, De Strooper B, Seed B: The cell adhesion protein P-selectin glycoprotein ligand-1 is a substrate for the aspartyl protease BACE1. J Biol Chem 2003, 278:48713-48719.

94. Kitazume S, Tachida Y, Oka R, Shirotani K, Saido TC, Hashimoto Y: Alzheimer's beta-secretase, beta-site amyloid precursor protein-cleaving enzyme, is responsible for cleavage secretion of a Golgi-resident sialyltransferase. Proc Natl Acad Sci USA 2001, 98:13554-13559.

95. Wong HK, Sakurai T, Oyama F, Kaneko K, Wada K, Miyazaki H, Kurosawa M, De Strooper B, Saftig P, Nukina N: Beta Subunits of voltage-gated sodium channels are novel substrates of beta-site amyloid precursor proteincleaving enzyme (BACE1) and gamma-secretase. J Biol Chem 2005, 280:23009-23017.

96. Dominguez D, Tournoy J, Hartmann D, Huth T, Cryns K, Deforce S, Serneels L, Camacho IE, Marjaux E, Craessaerts K, et al: Phenotypic and biochemical analyses of BACE1- and BACE2-deficient mice. J Biol Chem 2005, 280:30797-30806.

97. Laird FM, Cai H, Savonenko AV, Farah MH, He K, Melnikova T, Wen H, Chiang HC, Xu G, Koliatsos VE, et al: BACE1, a major determinant of selective vulnerability of the brain to amyloid-beta amyloidogenesis, is essential for cognitive, emotional, and synaptic functions. J Neurosci 2005, 25:11693-11709.

98. McConlogue L, Buttini M, Anderson JP, Brigham EF, Chen KS, Freedman SB, Games D, Johnson-Wood K, Lee M, Zeller M, et al: Partial reduction of BACE1 has dramatic effects on Alzheimer plaque and synaptic pathology in APP Transgenic Mice. J Biol Chem 2007, 282:26326-26334.

99. Haniu M, Denis P, Young Y, Mendiaz EA, Fuller J, Hui JO, Bennett BD, Kahn S, Ross S, Burgess T, et al: Characterization of Alzheimer's beta -secretase protein BACE. A pepsin family member with unusual properties. $J$ Biol Chem 2000, 275:21099-21106.

100. Benjannet S, Elagoz A, Wickham L, Mamarbachi M, Munzer JS, Basak A Lazure C, Cromlish JA, Sisodia S, Checler F, et al: Post-translational processing of beta-secretase (beta-amyloid-converting enzyme) and its ectodomain shedding. The pro- and transmembrane/cytosolic domains affect its cellular activity and amyloid-beta production. J Biol Chem 2001, 276:10879-10887.

101. Bennett BD, Denis P, Haniu M, Teplow DB, Kahn S, Louis JC, Citron M, Vassar R: A furin-like convertase mediates propeptide cleavage of BACE, the Alzheimer's beta -secretase. J Biol Chem 2000, 275:37712-37717.

102. Creemers JW, Ines Dominguez D, Plets E, Serneels L, Taylor NA, Multhaup G, Craessaerts K, Annaert W, De Strooper B: Processing of beta-secretase by furin and other members of the proprotein convertase family. J Biol Chem 2001, 276:4211-4217.

103. Shi XP, Chen E, Yin KC, Na S, Garsky VM, Lai MT, Li YM, Platchek M, Register RB, Sardana MK, et al: The pro domain of beta-secretase does not confer strict zymogen-like properties but does assist proper folding of the protease domain. J Biol Chem 2001, 276:10366-10373.

104. Walter J, Fluhrer R, Hartung B, Willem M, Kaether C, Capell A, Lammich S, Multhaup G, Haass C: Phosphorylation regulates intracellular trafficking of beta-secretase. J Biol Chem 2001, 276:14634-14641.

105. Huse JT, Pijak DS, Leslie GJ, Lee VM, Doms RW: Maturation and endosomal targeting of beta-site amyloid precursor protein-cleaving enzyme. The Alzheimer's disease beta-secretase. J Biol Chem 2000, 275:33729-33737.

106. Huse JT, Liu K, Pijak DS, Carlin D, Lee VM, Doms RW: Beta-secretase processing in the trans-Golgi network preferentially generates truncated amyloid species that accumulate in Alzheimer's disease brain. J Biol Chem 2002, 277:16278-16284.

107. Das U, Scott DA, Ganguly A, Koo EH, Tang Y, Roy S: Activity-induced convergence of APP and BACE-1 in acidic microdomains via an endocytosis-dependent pathway. Neuron 2013, 79:447-460.

108. Bonifacino JS: The GGA proteins: adaptors on the move. Nat Rev Mol Cell Biol 2004, 5:23-32

109. Boman AL, Zhang C, Zhu X, Kahn RA: A family of ADP-ribosylation factor effectors that can alter membrane transport through the trans-Golgi. Mol Biol Cell 2000, 11:1241-1255.

110. Puertollano R, Randazzo PA, Presley JF, Hartnell LM, Bonifacino JS: The GGAs promote ARF-dependent recruitment of clathrin to the TGN. Cell 2001, 105:93-102.
111. Wang J, Sun $H Q$, Macia E, Kirchhausen $T$, Watson $H$, Bonifacino JS, Yin $H L$ : PI4P promotes the recruitment of the GGA adaptor proteins to the trans-Golgi network and regulates their recognition of the ubiquitin sorting signal. Mol Biol Cell 2007, 18:2646-2655.

112. Nadimpalli SK, Amancha PK: Evolution of mannose 6-phosphate receptors (MPR300 and 46): lysosomal enzyme sorting proteins. Curr Protein Pept Sci 2010, 11:68-90.

113. He X, Chang WP, Koelsch G, Tang J: Memapsin 2 (beta-secretase) cytosolic domain binds to the VHS domains of GGA1 and GGA2: implications on the endocytosis mechanism of memapsin 2. FEBS Lett 2002, 524:183-187.

114. He X, Li F, Chang WP, Tang J: GGA proteins mediate the recycling pathway of memapsin 2 (BACE). J Biol Chem 2005, 280:11696-11703.

115. von Arnim CA, Tangredi MM, Peltan ID, Lee BM, Irizarry MC, Kinoshita A, Hyman BT: Demonstration of BACE (beta-secretase) phosphorylation and its interaction with GGA1 in cells by fluorescence-lifetime imaging microscopy. J Cell Sci 2004, 117:5437-5445.

116. Wahle T, Thal DR, Sastre M, Rentmeister A, Bogdanovic N, Famulok M, Heneka MT, Walter J: GGA1 is expressed in the human brain and affects the generation of amyloid beta-peptide. J Neurosci 2006, 26:12838-12846.

117. Wahle T, Prager K, Raffler N, Haass C, Famulok M, Walter J: GGA proteins regulate retrograde transport of BACE1 from endosomes to the trans-Golgi network. Mol Cell Neurosci 2005, 29:453-461.

118. Herskowitz JH, Offe K, Deshpande A, Kahn RA, Levey Al, Lah JJ: GGA1-mediated endocytic traffic of LR11/SorLA alters APP intracellular distribution and amyloid-beta production. Mol Biol Cell 2012, 23:2645-2657.

119. Haass C, Kaether C, Thinakaran G, Sisodia S: Trafficking and proteolytic processing of APP. Cold Spring Harb Perspect Med 2012, 2:a006270.

120. Tesco G, Koh YH, Kang EL, Cameron AN, Das S, Sena-Esteves M, Hiltunen M, Yang SH, Zhong Z, Shen Y, et al: Depletion of GGA3 stabilizes BACE and enhances beta-secretase activity. Neuron 2007, 54:721-737.

121. Natunen T, Parrado AR, Helisalmi S, Pursiheimo JP, Sarajarvi T, Makinen $P$, Kurkinen KM, Mullin K, Alafuzoff I, Haapasalo A, et al: Elucidation of the BACE1 regulating factor GGA3 in Alzheimer's disease. J Alzheimers Dis 2013, 37:217-232.

122. Kang EL, Cameron AN, Piazza F, Walker KR, Tesco G: Ubiquitin regulates GGA3-mediated degradation of BACE1. J Biol Chem 2010, 285:24108-24119.

123. Seaman MN, McCaffery JM, Emr SD: A membrane coat complex essential for endosome-to-Golgi retrograde transport in yeast. J Cell Biol 1998, 142:665-681.

124. Lane RF, Raines SM, Steele JW, Ehrlich ME, Lah JA, Small SA, Tanzi RE, Attie AD, Gandy S: Diabetes-associated SorCS1 regulates Alzheimer's amyloid-beta metabolism: evidence for involvement of SorL1 and the retromer complex. J Neurosci 2010, 30:13110-13115.

125. Wen L, Tang FL, Hong Y, Luo SW, Wang CL, He W, Shen C, Jung JU, Xiong F, Lee DH, et al: VPS35 haploinsufficiency increases Alzheimer's disease neuropathology. J Cell Biol 2011, 195:765-779.

126. Bhalla A, Vetanovetz CP, Morel E, Chamoun Z, Di Paolo G, Small SA: The location and trafficking routes of the neuronal retromer and its role in amyloid precursor protein transport. Neurobiol Dis 2012, 47:126-134.

127. Small SA, Kent K, Pierce A, Leung C, Kang MS, Okada H, Honig L, Vonsattel JP, Kim TW: Model-guided microarray implicates the retromer complex in Alzheimer's disease. Ann Neurol 2005, 58:909-919.

128. Okada H, Zhang W, Peterhoff C, Hwang JC, Nixon RA, Ryu SH, Kim TW: Proteomic identification of sorting nexin 6 as a negative regulator of BACE1-mediated APP processing. FASEB J 2010, 24:2783-2794.

129. Zhao Y, Wang Y, Yang J, Wang X, Zhang X, Zhang YW: Sorting nexin 12 interacts with BACE1 and regulates BACE1-mediated APP processing. Mol Neurodegener 2012, 7:30.

130. Sannerud R, Declerck I, Peric A, Raemaekers T, Menendez G, Zhou L, Veerle B, Coen K, Munck S, De Strooper B, et al: ADP ribosylation factor 6 (ARF6) controls amyloid precursor protein (APP) processing by mediating the endosomal sorting of BACE1. Proc Natl Acad Sci USA 2011, 108:E559-E568.

131. Zhao Y, Wang Y, Hu J, Zhang X, Zhang YW: CutA divalent cation tolerance homolog (Escherichia coli) (CUTA) regulates beta-cleavage of beta-amyloid precursor protein (APP) through interacting with beta-site APP cleaving protein 1 (BACE1). J Biol Chem 2012, 287:11141-11150.

132. Murayama KS, Kametani F, Saito S, Kume H, Akiyama H, Araki W: Reticulons RTN3 and RTN4-B/C interact with BACE1 and inhibit its ability to produce amyloid beta-protein. Eur J Neurosci 2006, 24:1237-1244. 
133. Chiurchiu V, Maccarrone M, Orlacchio A: The role of reticulons in neurodegenerative diseases. Neuromolecular Med 2013. doi:10.1007/ s12017-013-8271-9.

134. Shi Q, Prior M, He W, Tang X, Hu X, Yan R: Reduced amyloid deposition in mice overexpressing RTN3 is adversely affected by preformed dystrophic neurites. J Neurosci 2009, 29:9163-9173.

135. He W, Lu Y, Qahwash I, Hu XY, Chang A, Yan R: Reticulon family members modulate BACE1 activity and amyloid-beta peptide generation. Nat Med 2004, 10:959-965

136. Park JH, Gimbel DA, GrandPre T, Lee JK, Kim JE, Li W, Lee DH, Strittmatter SM: Alzheimer precursor protein interaction with the Nogo- 66 receptor reduces amyloid-beta plaque deposition. J Neurosci 2006, 26:1386-1395.

137. Zhou X, Hu X, He W, Tang X, Shi Q, Zhang Z, Yan R: Interaction between amyloid precursor protein and Nogo receptors regulates amyloid deposition. FASEB J 2011, 25:3146-3156.

138. Haass C, De Strooper B: The presenilins in Alzheimer's disease-proteolysis holds the key. Science 1999, 286:916-919.

139. Wang R, Tang P, Wang P, Boissy RE, Zheng H: Regulation of tyrosinase trafficking and processing by presenilins: partial loss of function by familial Alzheimer's disease mutation. Proc Natl Acad Sci USA 2006, 103:353-358.

140. Kimberly WT, LaVoie MJ, Ostaszewski BL, Ye W, Wolfe MS, Selkoe DJ: Gamma-secretase is a membrane protein complex comprised of presenilin, nicastrin, Aph-1, and Pen-2. Proc Natl Acad Sci USA 2003, 100:6382-6387.

141. Takasugi N, Tomita T, Hayashi I, Tsuruoka M, Niimura M, Takahashi Y, Thinakaran G, Iwatsubo T: The role of presenilin cofactors in the gamma-secretase complex. Nature 2003, 422:438-441.

142. Kim J, Schekman R: The ins and outs of presenilin 1 membrane topology. Proc Natl Acad Sci USA 2004, 101:905-906.

143. Wolfe MS, Xia W, Ostaszewski BL, Diehl TS, Kimberly WT, Selkoe DJ: Two transmembrane aspartates in presenilin-1 required for presenilin endoproteolysis and gamma-secretase activity. Nature 1999, 398:513-517.

144. Shah S, Lee SF, Tabuchi K, Hao YH, Yu C, LaPlant Q, Ball H, Dann CE 3rd, Sudhof T, Yu G: Nicastrin functions as a gamma-secretase-substrate receptor. Cell 2005, 122:435-447.

145. Luo WJ, Wang H, Li H, Kim BS, Shah S, Lee HJ, Thinakaran G, Kim TW, Yu G, $\mathrm{Xu} \mathrm{H}$ : PEN-2 and APH-1 coordinately regulate proteolytic processing of presenilin 1. J Biol Chem 2003, 278:7850-7854.

146. Ahn K, Shelton CC, Tian Y, Zhang X, Gilchrist ML, Sisodia SS, Li YM: Activation and intrinsic \{gamma\}-secretase activity of presenilin 1. Proc Natl Acad Sci USA 2010, 107:21435-21440.

147. St George-Hyslop P, Fraser PE: Assembly of the presenilin gamma-/epsilonsecretase complex. J Neurochem 2012, 120(Suppl 1):84-88.

148. Pasternak SH, Callahan JW, Mahuran DJ: The role of the endosomal/ lysosomal system in amyloid-beta production and the pathophysiology of Alzheimer's disease: reexamining the spatial paradox from a lysosomal perspective. J Alzheimers Dis 2004, 6:53-65.

149. Kaether C, Schmitt S, Willem M, Haass C: Amyloid precursor protein and Notch intracellular domains are generated after transport of their precursors to the cell surface. Traffic 2006, 7:408-415.

150. Nixon RA: Autophagy, amyloidogenesis and Alzheimer disease. J Cell Sci 2007, 120:4081-4091.

151. Dries DR, Yu G: Assembly, maturation, and trafficking of the gammasecretase complex in Alzheimer's disease. Curr Alzheimer Res 2008, 5:132-146.

152. Vetrivel KS, Zhang YW, Xu H, Thinakaran G: Pathological and physiological functions of presenilins. Mol Neurodegener 2006, 1:4

153. Liu Y, Zhang YW, Wang X, Zhang H, You X, Liao FF, Xu H: Intracellular trafficking of presenilin 1 is regulated by beta-amyloid precursor protein and phospholipase D1. J Biol Chem 2009, 284:12145-12152.

154. Salehi A, Delcroix JD, Belichenko PV, Zhan K, Wu C, Valletta JS, Takimoto-Kimura R, Kleschevnikov AM, Sambamurti K, Chung PP, et al: Increased App expression in a mouse model of Down's syndrome disrupts NGF transport and causes cholinergic neuron degeneration. Neuron 2006, 51:29-42.

155. Kamal A Almenar-Queralt A, LeBlanc JF, Roberts EA, Goldstein LS. Kinesinmediated axonal transport of a membrane compartment containing beta-secretase and presenilin-1 requires APP. Nature 2001, 414:643-648.

156. Wu J, Petralia RS, Kurushima H, Patel H, Jung MY, Volk L, Chowdhury S, Shepherd JD, Dehoff M, Li Y, et al: Arc/Arg3.1 regulates an endosomal pathway essential for activity-dependent beta-amyloid generation. Cell 2011, 147:615-628.

157. Ni Y, Zhao X, Bao G, Zou L, Teng L, Wang Z, Song M, Xiong J, Bai Y, Pei G: Activation of beta2-adrenergic receptor stimulates gamma-secretase activity and accelerates amyloid plaque formation. Nat Med 2006, 12:1390-1396.

158. Thathiah A, Spittaels K, Hoffmann M, Staes M, Cohen A, Horre K, Vanbrabant M, Coun F, Baekelandt V, Delacourte A, et al: The orphan G protein-coupled receptor 3 modulates amyloid-beta peptide generation in neurons. Science 2009, 323:946-951.

159. Thathiah A, Horre K, Snellinx A, Vandewyer E, Huang Y, Ciesielska M, De Kloe G, Munck S, De Strooper B: Beta-arrestin 2 regulates Abeta generation and gamma-secretase activity in Alzheimer's disease. Nat Med 2013, 19:43-49.

160. Lefkowitz RJ: G protein-coupled receptors. III. New roles for receptor kinases and beta-arrestins in receptor signaling and desensitization. J Biol Chem 1998, 273:18677-18680.

161. Nelson CD, Sheng M: Gpr3 stimulates Abeta production via interactions with APP and beta-arrestin2. PLoS One 2013, 8:e74680.

162. Liu X, Zhao X, Zeng X, Bossers K, Swaab DF, Zhao J, Pei G: Beta-arrestin1 regulates gamma-secretase complex assembly and modulates amyloidbeta pathology. Cell Res 2013, 23:351-365.

163. Spasic D, Raemaekers T, Dillen K, Declerck I, Baert V, Serneels L, Fullekrug J, Annaert W: Rer1p competes with APH-1 for binding to nicastrin and regulates gamma-secretase complex assembly in the early secretory pathway. J Cell Biol 2007, 176:629-640.

164. Kaether C, Scheuermann J, Fassler M, Zilow S, Shirotani K, Valkova C, Novak B, Kacmar S, Steiner $\mathrm{H}$, Haass $\mathrm{C}$ : Endoplasmic reticulum retention of the gamma-secretase complex component Pen2 by Rer1. EMBO Rep 2007 , 8:743-748.

165. Park HJ, Shabashvili D, Nekorchuk MD, Shyqyriu E, Jung JI, Ladd TB, Moore BD, Felsenstein KM, Golde TE, Kim SH: Retention in endoplasmic reticulum 1 (RER1) modulates amyloid-beta (Abeta) production by altering trafficking of gamma-secretase and amyloid precursor protein (APP). J Biol Chem 2012, 287:40629-40640.

166. Mace S, Cousin E, Ricard S, Genin E, Spanakis E, Lafargue-Soubigou C, Genin B, Fournel $R$, Roche $S$, Haussy $G$, et al: $A B C A 2$ is a strong genetic risk factor for early-onset Alzheimer's disease. Neurobiol Dis 2005, 18:119-125.

167. Wollmer MA, Kapaki E, Hersberger M, Muntwyler J, Brunner F, Tsolaki M, Akatsu H, Kosaka K, Michikawa M, Molyva D, et al: Ethnicity-dependent genetic association of ABCA2 with sporadic Alzheimer's disease. Am J Med Genet B Neuropsychiatr Genet 2006, 141B:534-536.

168. Michaki V, Guix FX, Vennekens K, Munck S, Dingwall C, Davis JB, Townsend DM, Tew KD, Feiguin F, De Strooper B, et al: Down-regulation of the ATP-binding cassette transporter 2 (Abca2) reduces amyloid-beta production by altering Nicastrin maturation and intracellular localization. J Biol Chem 2012, 287:1100-1111.

169. Camden JM, Schrader AM, Camden RE, Gonzalez FA, Erb L, Seye Cl, Weisman GA: P2Y2 nucleotide receptors enhance alpha-secretase-dependent amyloid precursor protein processing. J Biol Chem 2005, 280:18696-18702.

170. Gardoni F, Saraceno C, Malinverno M, Marcello E, Verpelli C, Sala C, Di Luca M: The neuropeptide PACAP38 induces dendritic spine remodeling through ADAM10-N-cadherin signaling pathway. J Cell Sci 2012, 125:1401-1406.

171. Wolf BA, Wertkin AM, Jolly YC, Yasuda RP, Wolfe BB, Konrad RJ, Manning D, Ravi S, Williamson JR, Lee VM: Muscarinic regulation of Alzheimer's disease amyloid precursor protein secretion and amyloid beta-protein production in human neuronal NT2N cells. J Biol Chem 1995, 270:4916-4922.

172. Fisher A, Pittel Z, Haring R, Bar-Ner N, Kliger-Spatz M, Natan N, Egozi I, Sonego H, Marcovitch I, Brandeis R: M1 muscarinic agonists can modulate some of the hallmarks in Alzheimer's disease: implications in future therapy. J Mol Neurosci 2003, 20:349-356.

173. Vincent B: ADAM proteases: protective role in Alzheimer's and prion diseases? Curr Alzheimer Res 2004, 1:165-174.

174. Janes PW, Saha N, Barton WA, Kolev MV, Wimmer-Kleikamp SH, Nievergall E Blobel CP, Himanen JP, Lackmann M, Nikolov DB: Adam meets Eph: an ADAM substrate recognition module acts as a molecular switch for ephrin cleavage in trans. Cell 2005, 123:291-304.

175. Brou C, Logeat F, Gupta N, Bessia C, LeBail O, Doedens JR, Cumano A Roux $\mathrm{P}$, Black RA, Israel A: A novel proteolytic cleavage involved in Notch signaling: the role of the disintegrin-metalloprotease TACE. Mol Cell 2000, 5:207-216. 
176. Weskamp G, Kratzschmar J, Reid MS, Blobel CP: MDC9, a widely expressed cellular disintegrin containing cytoplasmic SH3 ligand domains. J Cell Biol 1996, 132:717-726.

177. Black RA, Rauch CT, Kozlosky CJ, Peschon JJ, Slack JL, Wolfson MF, Castner BJ, Stocking KL, Reddy P, Srinivasan S, et al: A metalloproteinase disintegrin that releases tumour-necrosis factor-alpha from cells. Nature 1997, 385:729-733.

178. Marcinkiewicz M, Seidah NG: Coordinated expression of beta-amyloid precursor protein and the putative beta-secretase BACE and alphasecretase ADAM10 in mouse and human brain. J Neurochem 2000, 75:2133-2143

179. Jorissen E, Prox J, Bernreuther C, Weber S, Schwanbeck R, Serneels L, Snellinx A, Craessaerts K, Thathiah A, Tesseur l, et al: The disintegrin/ metalloproteinase ADAM10 is essential for the establishment of the brain cortex. J Neurosci 2010, 30:4833-4844.

180. Allinson TM, Parkin ET, Turner AJ, Hooper NM: ADAMs family members as amyloid precursor protein alpha-secretases. J Neurosci Res 2003, 74:342-352.

181. Kuhn PH, Wang H, Dislich B, Colombo A, Zeitschel U, Ellwart JW, Kremmer E, Rossner S, Lichtenthaler SF: ADAM10 is the physiologically relevant, constitutive alpha-secretase of the amyloid precursor protein in primary neurons. EMBO J 2010, 29:3020-3032.

182. Tyler SJ, Dawbarn D, Wilcock GK, Allen SJ: Alpha- and beta-secretase: profound changes in Alzheimer's disease. Biochem Biophys Res Commun 2002, 299:373-376.

183. Colciaghi F, Borroni B, Pastorino L, Marcello E, Zimmermann M, Cattabeni $F$, Padovani A, Di Luca M: [Alpha]-Secretase ADAM10 as well as [alpha]APPs is reduced in platelets and CSF of Alzheimer disease patients. Mol Med 2002, 8:67-74.

184. Merlos-Suarez A, Ruiz-Paz S, Baselga J, Arribas J: Metalloproteasedependent protransforming growth factor-alpha ectodomain shedding in the absence of tumor necrosis factor-alpha-converting enzyme. J Biol Chem 2001, 276:48510-48517.

185. Lammich S, Kojro E, Postina R, Gilbert S, Pfeiffer R, Jasionowski M, Haass C Fahrenholz F: Constitutive and regulated alpha-secretase cleavage of Alzheimer's amyloid precursor protein by a disintegrin metalloprotease. Proc Natl Acad Sci USA 1999, 96:3922-3927.

186. Schafer W, Stroh A, Berghofer S, Seiler J, Vey M, Kruse ML, Kern HF, Klenk HD, Garten W: Two independent targeting signals in the cytoplasmic domain determine trans-Golgi network localization and endosomal trafficking of the proprotein convertase furin. EMBO J 1995, 14:2424-2435.

187. Wouters S, Leruth M, Decroly E, Vandenbranden M, Creemers JW, van de Loo JW, Ruysschaert JM, Courtoy PJ: Furin and proprotein convertase 7 (PC7)/ lymphoma PC endogenously expressed in rat liver can be resolved into distinct post-Golgi compartments. Biochem J 1998, 336(Pt 2):311-316.

188. Parvathy S, Hussain I, Karran EH, Turner AJ, Hooper NM: Cleavage of Alzheimer's amyloid precursor protein by alpha-secretase occurs at the surface of neuronal cells. Biochemistry 1999, 38:9728-9734.

189. Skovronsky DM, Moore DB, Milla ME, Doms RW, Lee VM: Protein kinase C-dependent alpha-secretase competes with beta-secretase for cleavage of amyloid-beta precursor protein in the trans-golgi network. J Biol Chem 2000, 275:2568-2575.

190. Huovila AP, Turner AJ, Pelto-Huikko M, Karkkainen I, Ortiz RM: Shedding light on ADAM metalloproteinases. Trends Biochem Sci 2005, 30:413-422.

191. Lichtenthaler SF: Alpha-secretase in Alzheimer's disease: molecular identity, regulation and therapeutic potential. J Neurochem 2011, 116:10-21.

192. Marcello E, Gardoni F, Di Luca M, Perez-Otano I: An arginine stretch limits ADAM10 exit from the endoplasmic reticulum. J Biol Chem 2010, 285:10376-10384.

193. Marcello E, Gardoni F, Mauceri D, Romorini S, Jeromin A, Epis R, Borroni B, Cattabeni F, Sala C, Padovani A, Di Luca M: Synapse-associated protein-97 mediates alpha-secretase ADAM10 trafficking and promotes its activity. J Neurosci 2007, 27:1682-1691.
194. Marcello E, Epis R, Saraceno C, Gardoni F, Borroni B, Cattabeni F, Padovani A, Di Luca M: SAP97-mediated local trafficking is altered in Alzheimer disease patients' hippocampus. Neurobiol Aging 2012, 33:422. e421-410.

195. Marcello E, Saraceno C, Musardo S, Vara H, de la Fuente AG, Pelucchi S, Di Marino D, Borroni B, Tramontano A, Perez-Otano I, et al: Endocytosis of synaptic ADAM10 in neuronal plasticity and Alzheimer's disease. J Clin Invest 2013, 123:2523-2538.

doi:10.1186/1750-1326-9-6

Cite this article as: Jiang et al:: Trafficking regulation of proteins in Alzheimer's disease. Molecular Neurodegeneration 2014 9:6.

\section{Submit your next manuscript to BioMed Central and take full advantage of:}

- Convenient online submission

- Thorough peer review

- No space constraints or color figure charges

- Immediate publication on acceptance

- Inclusion in PubMed, CAS, Scopus and Google Scholar

- Research which is freely available for redistribution

Submit your manuscript at www.biomedcentral.com/submit
C Biomed Central 